\title{
A New Role for the Renin-angiotensin System in the Development of the Ureteric Bud and Renal Collecting System
}

\author{
Ihor V. Yosypiv \\ Division of Pediatric Nephrology, Department of Pediatrics, \\ Tulane University Health Sciences Center, New Orleans, USA
}

(Received for publication on April 22, 2008)

(Accepted for publication on June 19, 2008)

\begin{abstract}
The renin-angiotensin system (RAS) plays a critical role in kidney development. Mutations in the genes encoding components of the RAS or pharmacological inhibition of RAS in mice or humans cause a spectrum of congenital abnormalities of the kidney and urinary tract (CAKUT). The observed defects include renal vascular abnormalities, abnormal glomerulogenesis, renal papillary hypoplasia, hydronephrosis, aberrant ureteric bud (UB) budding, duplicated collecting system and renal tubular dysgenesis. Little is known about the potential role of Ang II and its receptors in the morphogenesis of the UB and renal collecting system. This review emphasizes a novel role for the RAS in the development of the UB, collecting ducts and renal medulla. We observe that UB and surrounding stroma express angiotensinogen and Ang II $\mathrm{AT}_{1}$ receptors $\left(\mathrm{AT}_{1} \mathrm{R}\right)$ in vivo. Ang II stimulates $\mathrm{UB}$ cell branching in collagen gel cultures in vitro and induces UB morphogenesis in intact whole embryonic metanephroi grown ex vivo. In contrast, treatment of metanephroi with the $\mathrm{AT}_{1} \mathrm{R}$ antagonist candesartan inhibits UB branching. In addition, Ang II induces tyrosine phosphorylation of the epidermal growth factor receptor (EGFR) in UB cells. Furthermore, Ang II-stimulated UB morphogenesis is abrogated by inhibition of EGFR tyrosine kinase activity. In summary: 1) Ang II, acting via the $\mathrm{AT}_{1} \mathrm{R}$, stimulates UB branching; 2) This process depends on tyrosine phosphorylation of the EGFR. Together, these data indicate that cooperation of $\mathrm{AT}_{1} \mathrm{R}$ and EGFR signaling performs essential functions during renal collecting system development via control of UB branching morphogenesis. (Keio J Med 57 (4) : 184189, December 2008)
\end{abstract}

Key words: kidney development, renin-angiotensin, metanephros, ureteric bud

\section{Introduction}

Congenital abnormalities of the kidney and urinary tract (CAKUT) are the major cause of renal failure in childhood. ${ }^{1}$ Many CAKUT have a genetic basis and are associated with hereditary human syndromes. ${ }^{2}$ The inheritance pattern of some CAKUT (autosomal-dominant or recessive polycystic kidney disease) is well known. ${ }^{3}$ In other nonsyndromic CAKUT (obstructive uropathy, vesico-ureteral reflux, kidney aplasia, duplex kidneys), the hereditary mechanisms remain to be determined. In this respect, recent discovery of a number of genes involved in coordination of metanephric development pro- vided a further impulse to explore in depth the pathogenesis of the CAKUT.

\section{Overview of Metanephric Kidney Development}

The development of the metanephric kidney begins when the nephric duct (ND) gives rise to ureteric bud (UB) on embryonic (E) day E10.5 in mice and E28 in humans (Fig. 1). The initial events controlling UB induction are regulated by numerous transcription factors and signaling molecules that are expressed in a specific spatial and temporal patterns. ${ }^{4}$ Signals from the mesenchyme induce the UB to originate from the ND, invade

Presented at the 1562nd meeting of the Keio Medical Society in Tokyo, May 9, 2008.

Corresponding Author: Ihor V. Yosypiv, M.D., Associate Professor, Department of Pediatrics, SL-37, Tulane University Health Sciences Center, New Orleans, LA70112, Tel: +1-504-988-5377, Fax: +1-504-988-1852, E-mail: iiosipi@tulane.edu 


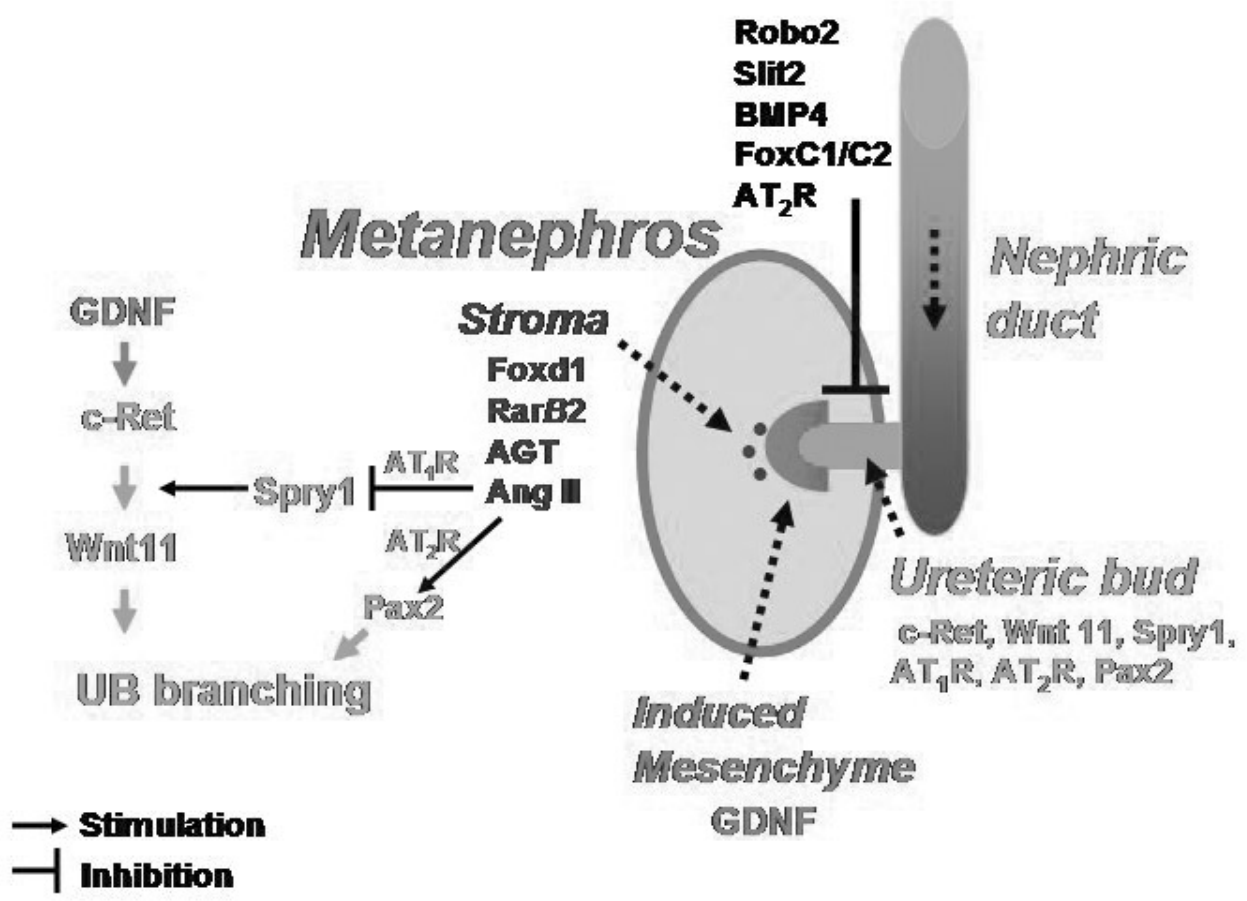

Fig. 1 Gene regulatory networks in kidney development. The nephric duct is formed from the intermediate mesoderm and extends caudally. On E10.5 in mice and E28 in humans, nephric duct forms an outgrowth, the ureteric bud (UB), which invades the mesenchyme. UB induces mesenchyme to undergo patterning into two compartments: induced (metanephrogenic) mesenchyme and stroma. Metanephrogenic and stromal mesenchymal compartments interact reciprocally with the UB to form the metanephros. Multiple gene regulatory networks have been shown to regulate UB elongation, branching and nephron formation. Robo2, Slit2, BMP4, FoxCl/C2 and $\mathrm{AT}_{2} \mathrm{R}$ act to restrict GDNF expression anteriorly and specify correct site of UB outgrowth from the nephric duct. $G D N F / c-R e t / W n t 11$ pathway is the major positive regulator of UB development. Angiotensinogen (AGT) and Ang II are novel stromal factors that regulate UB morphogenesis. Ang II, acting via the $\mathrm{AT}_{1} \mathrm{R}$, inhibits Spryl expression and thereby releaves inhibition of signaling via the GDNF/c-Ret/Wnt11 pathway. Acting via the $\mathrm{AT}_{2} \mathrm{R}$, Ang II upregulates Pax2. This stimulates UB branching.

the mesenchyme and then branch repeatedly by a process called branching morphogenesis (Fig. 2). Initial generations of UB branches will be remodeled into the ureter and collecting system. Subsequent generations of UB branches will differentiate into collecting ducts. Collecting ducts will subsequently undergo patterning to contribute importantly to the renal papilla and medulla. Each UB tip is capable of inducing the adjacent metanephrogenic mesenchyme (MM) to undergo mesenchymal-to-epithelial transition (MET) and form nephrons (from the glomerulus to the distal tubule). ${ }^{12}$ Therefore, UB branching morphogenesis is critical in determining total nephron number, proper kidney size and structure.

The GDNF/c-Ret/Wnt11 signaling pathway is a major positive regulator of UB induction and branching in the metanephros (Fig. 1). ${ }^{5}$ Glial-derived neurotrophic factor $(G D N F)$ is released from the $\mathrm{MM}$ and interacts with the $c$-Ret tyrosine kinase receptor expressed in the UB tip cells to induce branching. ${ }^{6}$ GDNF/c-Ret and Wnt 11 cooperate to maintain continued UB branching. ${ }^{6,7}$ The activity of the GDNF-c-Ret-Wnt11 pathway is inhibited by Spry $1 .{ }^{8}$ The correct site of initial UB induction is speci- fied by restricting $G D N F$ expression within the specified domain of the mesenchyme by Robo2/Slit $2 /$ FoxCl/ FoxC $2 .^{9-11}$ Interestingly, mutations in the genes expressed in the stromal mesenchyme compromise both UB branching and MET. ${ }^{13,14}$ Therefore, even subtle aberrations in reciprocal interactions among the UB, MM and stroma have profound effect on the ultimate development of the kidney and appearance of CAKUT.

\section{Role of the Renin-angiotensin System in Metanephric Kidney Development}

The developing metanephric kidney expresses all the components of the renin-angiotensin system (RAS). ${ }^{15-17}$ The activity of the intrarenal RAS is high during fetal and neonatal life and declines during postnatal maturation. Renin mRNA and angiotensin (Ang) II levels are remarkably higher, respectively, in newborn than adult kidneys. ${ }^{15,18} \mathrm{AT}_{1}\left(\mathrm{AT}_{1} \mathrm{R}\right)$ and $\mathrm{AT}_{2}\left(\mathrm{AT}_{2} \mathrm{R}\right)$ receptors are abundantly expressed in the nephrogenic area. ${ }^{19}$ The ontogenic expression of $\mathrm{AT}_{1} \mathrm{R}$ and $\mathrm{AT}_{2} \mathrm{R}$ in the metanephros differs. $\mathrm{AT}_{2} \mathrm{R}$ is expressed earlier than $\mathrm{AT}_{1} \mathrm{R}$, peaks during 


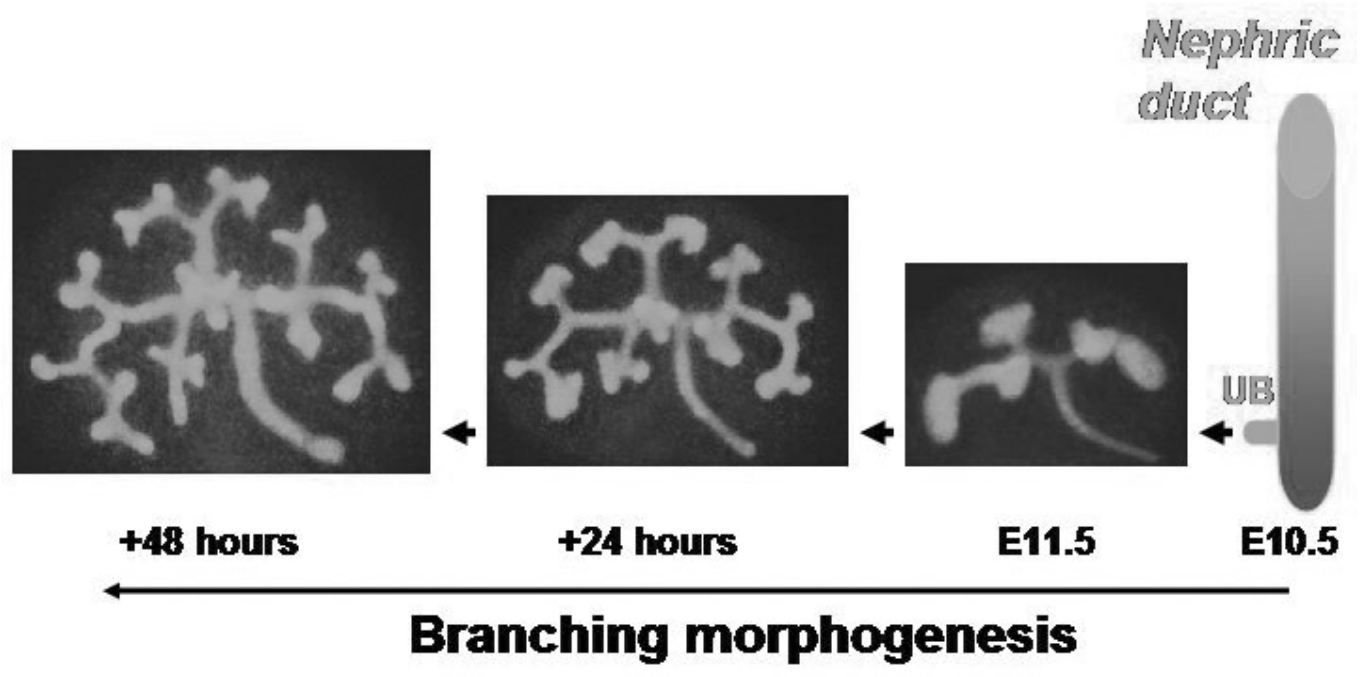

Fig. 2 Ureteric bud branching morphogenesis in the mouse. Ureteric bud (UB) emerges from the nephric duct on embryonic (E) day E10.5. Metanephros isolated on E11.5 from Hoxb7-GFP transgenic mouse embryo and grown ex vivo for 48 hours. Hoxb7 promoter directs expression of green fluorescent protein (GFP) to the UB. The number of branching structures increases progressively with time.

fetal life and rapidly declines postnatally. ${ }^{19,20} \mathrm{AT}_{1} \mathrm{R}$ expression increases during gestation, peaks perinatally and declines gradually thereafter. ${ }^{20}$ Spatially, $\mathrm{AT}_{1} \mathrm{R}$ is present in glomeruli, in distal and proximal tubules, whereas $\mathrm{AT}_{2} \mathrm{R}$ is expressed in mesenchymal cells adjacent to the UB stalk.

Genetic inactivation of the RAS components in mice or pharmacologic antagonism of the RAS cause a spectrum of abnormalities in the development of the ureter, renal pelvis and papilla. ${ }^{21-27}$ Angiotensinogen, angiotensin-converting enzyme (ACE) or $\mathrm{AT}_{1} \mathrm{R}$-deficient mice manifest hydronephrosis, hypoplastic medulla and papilla. Functionally, $\mathrm{ACE}$ and $\mathrm{AT}_{1} \mathrm{R}$ null animals also have a reduced ability to concentrate urine. ${ }^{24,25}$ Elegant studies from Dr. Ichikawa's laboratory have suggested that antagonism of $\mathrm{AT}_{1} \mathrm{R}$ signaling in ureteral smooth muscle cells impairs smooth muscle development in the ureter as well as its peristalsis. ${ }^{28}$ Treatment with ACE inhibitors or $\mathrm{AT}_{1} \mathrm{R}$ antagonists during gestation or postnatal metanephrogenesis leads to renal tissue dysplasia, a decrease in the number and size of glomeruli, renal arteries and delay in glomerulogenesis. ${ }^{29-31}$ Use of ACE inhibitors and $\mathrm{AT}_{1} \mathrm{R}$ blockers in humans cause oligohydramnios and anuria. ${ }^{32,33}$ Therefore, these drugs should not be used by pregnant women.

$\mathrm{AT}_{2} \mathrm{R}$ is expressed between the ND and the metanephrogenic mesenchyme anterior to the normal branching site in wild-type mice on E11. ${ }^{34,35} \mathrm{AT}_{2} \mathrm{R}$-mutant mice demonstrate a decrease in the rate of apoptosis of mesenchymal cells around the nascent UB. ${ }^{35}$ Mutations in the
$\mathrm{AT}_{2} \mathrm{R}$ gene in mice are associated with increased incidence of duplex ureters and vesicoureteral reflux. ${ }^{34}$ Thus, it is conceivable that $\mathrm{AT}_{2} \mathrm{R}$ may mark mesenchymal cells destined to undergo apoptosis and that absence of timely apoptosis of these cells may cause an aberrant UB budding and lead to duplicated ureters. In addition, $\mathrm{AT}_{2} \mathrm{R}$ may act as restricting signal to limit anterior expansion of the GDNF domain (Fig. 1).

Mutations in the genes encoding for angiotensinogen, renin, $\mathrm{ACE}$ or $\mathrm{AT}_{1} \mathrm{R}$ in humans lead to renal tubular dysgenesis (RTD). ${ }^{36,37}$ In RTD, renal cortex exhibits a paucity of proximal tubules. In the medulla, collapsed collecting ducts and abundant interstitial fibrosis are observed. ${ }^{37}$ Importantly, RTD in humans is characterized by perinatal death due to anuria combined with pulmonary hypoplasia. The more severe outcome in humans than in mice without the functional RAS may be due to the temporal difference in completion of nephrogenesis. In mice, nephrogenesis is completed 2 weeks after birth, whereas in humans- at 38 weeks of gestation. Collectively, the observed abnormalities in UB/medullary development imply that UB-derived structures are targets for Ang II actions during metanephric development in both mice and humans.

\section{Role of the Renin-angiotensin System in Ureteric Bud Morphogenesis}

To examine the importance of the RAS in UB development, we recently tested the hypothesis that Ang II, act- 
ing via $\mathrm{AT}_{1} \mathrm{R}$, stimulates $\mathrm{UB}$ branching morphogenesis. Immunohistochemistry demonstrated that angiotensinogen and $\mathrm{AT}_{1} \mathrm{R}$ are present in both UBs and the stromal mesenchyme on embryonic (E) day E12 in the mouse and that their expression increases progressively from E12 to E16. ${ }^{38}$ Importantly, $\mathrm{AT}_{1} \mathrm{R}$ immunoreactivity was present on both luminal and basolateral aspects of UB branches. ${ }^{38}$ Since juxtaglomerular renin-producing cells originate from the mesenchyme on E11-E12, at a time when UB branching is just beginning, ${ }^{39}$ Ang II may be generated locally in the mesenchyme to act in a paracrine fashion on the adjacent $\mathrm{AT}_{1} \mathrm{R}$-expressing $\mathrm{UBs}$ to regulate branching. $\mathrm{AT}_{1} \mathrm{R}$ expressed in the mesenchyme may mediate mesenchymal Ang II signaling to stimulate UB branching. Since fibroblast growth factor (FGF) 7 is expressed in the stromal mesenchyme, and that Ang II increases FGF7 mRNA levels in luteal cells,${ }^{40}$ it is conceivable that Ang II may regulate UB branching via induction of FGF7 in the stroma.

Given that cultured UB-derived cells (UB cells) maintain expression of $\mathrm{AT}_{1} \mathrm{R}$ mRNA and protein, we next investigated the direct role of Ang II and $A_{1} R$ in UB branching morphogenesis in UB cells ${ }^{38}$. Because utilization of UB cell culture model allows to avoid confounding influence of the mesenchyme, it is more relevant to define the direct role of Ang II in UB development. Ang II $\left(10^{-5} \mathrm{M}\right)$ increased the number and complexity of UB cells processes grown in three-dimensional collagen matrix gels. Ang II-induced increase in UB cell branching was prevented by $\mathrm{AT}_{1} \mathrm{R}$ antagonist candesar$\tan \left(10^{-6} \mathrm{M}\right)$. These data demonstrate that Ang II stimulates cell process formation and branching cord extension in UB cells in vitro via activation of the $A_{1} R$.

We further tested the role of Ang II in UB branching morphogenesis in the intact metanephric kidney where mesenchymal-epithelial interactions are intact. To determine the role of Ang II in early stages of UB development in the whole metanephros, we utilized embryonic kidneys obtained from Hoxb7-GFP transgenic mice which express green fluorescent protein (GFP) exclusively in the UB. ${ }^{41}$ Quantitative analysis of UB branching morphogenesis demonstrated that exogenous Ang II increased the number of UB tips and branch points compared to control. ${ }^{42}$ To examine the role of endogenous Ang II and $\mathrm{AT}_{1} \mathrm{R}$ in UB branching in the metanephros, we utilized the $\mathrm{AT}_{1} \mathrm{R}$ antagonist candesartan. Treatment of E11.5 metanephroi with candesartan $\left(10^{-6} \mathrm{M}\right)$ decreased the number of UB tips and branch points compared to control. These findings demonstrate that Ang II, acting via the $\mathrm{AT}_{1} \mathrm{R}$, stimulates UB branching morphogenesis in the intact metanephros.

The findings of angiotensinogen and renin in the stroma, and of $\mathrm{AT}_{1} \mathrm{R}$ in the UB epithelia during active UB branching in vivo, together with $\mathrm{AT}_{1} \mathrm{R}$-mediated increase in UB branching in vitro suggest that angiotensinogen and Ang II may represent novel stromal factors that regulate UB branching morphogenesis (Fig. 1). It will be crucial to delineate the effects of the $\mathrm{AT}_{1} \mathrm{R}$ null mutation on expression of stromal factors necessary for proper UB branching (Foxd1, FGF7, Wnt2b, pbx, p57 and retinoic acid receptors). This will allow better understanding of the mechanisms regulating the development of the renal medulla and papilla.

Collectively, our data suggest that papillary hypoplasia in RAS-deficient mice is due, in part, to an intrinsic defect in UB branching and aberrant development of the renal medulla. Indeed, Ang II may regulate multiple steps of renal collecting system development. During early metanephric development, Ang II is formed in the stromal mesenchyme and acts on $\mathrm{AT}_{1} \mathrm{R}$ and $\mathrm{AT}_{2} \mathrm{R}$ located on UBs to stimulate branching (Fig. 1). Later in metanephric development, Ang II stimulates patterning of UB-derived collecting ducts, pelvis and ureter.

Given that stimulation of the epidermal growth factor receptor (EGFR) induces branching morphogenesis in murine inner medullary collecting duct (IMCD3) cells $\mathrm{s}^{43}, 44$ and that renal papilla of angiotensinogen- and $\mathrm{AT}_{1} \mathrm{R}$-deficient mice exhibits reduced EGF mRNA levels, ${ }^{45}$ we next investigated the contribution of EGFR activation to Ang II-induced UB branching. Ang II increased tyrosine phosphorylation of EGFR in UB cells. ${ }^{42}$ Inhibition of EGFR tyrosine kinase activity abrogated Ang II-induced cell process formation in UB cells and UB branching in the intact metanephros. ${ }^{42}$ These findings indicate that cooperation of $\mathrm{AT}_{1} \mathrm{R}$ and EGFR signaling promotes the development of the renal collecting system.

Ang II can stimulate UB branching directly or through interaction with other factors present in the metanephrogenic mesenchyme, stroma or the UB that are known to regulate UB morphogenesis (Fig. 1). For example, Ang II may stimulate Pax2 present in the UB and thereby enhance UB branching. These possibility is supported by the ability of Ang II to increase Pax2 expression in metanephric kidney. ${ }^{46}$ Since $G D N F / c-$ Ret/Wnt11 signaling plays a major role in promoting UB morphogenesis, we recently examined the role of this pathway in Ang II-induced UB branching. Our preliminary findings demonstrate that Ang II enhances GDNF, c-Ret and Wnt11 expression in the UB tip cells and indicate that activation of this pathway by Ang II plays a critical role in Ang IImediated signaling to stimulate UB development. ${ }^{47}$ Since Spryl is a negative regulator of the GDNF/ c-Ret/Wnt11 pathway, we tested the hypothesis that Ang II inhibits Spryl gene expression. Our preliminary data indicate that Ang II downregulates Spryl expression in the UB in the intact embryonic kidneys grown ex vivo. ${ }^{47}$ Furthermore, downregulation of Spryl expression is prevented by antagonism of the $\mathrm{AT}_{1} \mathrm{R}$. Therefore, Ang II may stimulate the GDNF/c-Ret/Wnt11 pathway indirectly 
via repression of Spryl (Fig. 1).

The role of $\mathrm{AT}_{2} \mathrm{R}$ in UB branching is beginning to emerge. $\mathrm{AT}_{2} \mathrm{R}$-mutant mice exhibit ectopic ureteral budding and duplicated collecting systems. ${ }^{34}$ This suggests that $\mathrm{AT}_{2} \mathrm{R}$ inhibits aberrant UB budding. It is conceivable that unopposed stimulation of $\mathrm{AT}_{2} \mathrm{R}$ in $\mathrm{AT}_{1} \mathrm{R}$ - mutant mice may hinder UB branching. Our preliminary data demonstrate that $\mathrm{AT}_{2} \mathrm{R}$ is expressed in UB branches during mouse nephrogenesis in vivo ${ }^{48}$ and that $\mathrm{AT}_{2} \mathrm{R}$ antagonist PD123319 inhibits Ang II-induced cell process formation in UB cells cultured in three-dimensional collagen matrix gels. ${ }^{49}$ The ultimate effect of Ang II on UB branching may depend on the balance between $\mathrm{AT}_{1} \mathrm{R}$ and $\mathrm{AT}_{2} \mathrm{R}$-mediated actions.

The signaling events linking Ang II receptors to UB branching morphogenesis remain to be determined. Several signaling pathways, including MAP kinase and PI3K/Akt, have been shown to mediate the effects of $\mathrm{AT}_{1} \mathrm{R}$ on renal cell proliferation. ${ }^{43}$ Thus, one of the possible mechanisms leading to Ang II-stimulated tyrosine kinase signaling may involve EGFR- or c-Ret-mediated stimulation of MAP kinase and PI3K/Akt pathways., ${ }^{4,43}$ $\mathrm{AT}_{2} \mathrm{R}$-dependent mesenchymal apoptosis ${ }^{35}$ may result from activation of MAP kinase phosphatase 1 leading to inactivation of ERK1/2. ${ }^{50} \mathrm{AT}_{2} \mathrm{R}$-dependent activation of Pax2 in whole metanephroi and mesenchymal cells is mediated by JAK2/STAT pathway ${ }^{23}$.

In addition to stimulating UB morphogenesis, paracrine distal nephron RAS may regulate the expression of renal function genes, control terminal differentiation of the collecting duct cells and promote acquisition of their mature physiological function. These possibilities are supported by the following observations: 1) Ang II, acting via $\mathrm{AT}_{1} \mathrm{R}$, regulates urinary concentrating ability; ${ }^{25}$ 2) In the adult animal, Ang II acts via basolateral $A T_{1} R$ to stimulate luminal alkalinization in rabbit cortical collecting duct; ${ }^{51} 3$ ) In rat collecting duct, Ang II regulates $\mathrm{H}^{+}$-ATPase and basolateral $\mathrm{K}$ channel activities. ${ }^{52,53}$

\section{Perspectives}

Future studies investigating the effect of UB- and stromal mesenchyme-specific inactivation of angiotensinogen, $\mathrm{AT}_{1} \mathrm{R}$ and $\mathrm{AT}_{2} \mathrm{R}$ on urinary system phenotype and the expression of the critical gene networks known to regulate UB branching, collecting duct/medullary/renal collecting system/ureteral patterning will provide essential information regarding the nature of events culminating in the formation of the mature metanephros.

\section{Acknowledgements}

The author would like to thank Mercedes Schroeder, Mary Kate Boh, Melissa Spera, Renfang Song and Samir El-Dahr for assistance with the original studies. The original work was supported by NIH Grant P20 RR17659 and NIH/NIDDK Grant DK071699-01 (Ihor Yosypiv).

\section{References}

1. Limwongse C, Clarren SK, Cassidy SB: Syndromes and malformations of the urinary tract. In: Barratt TM, Avner ED, Harmon WE, eds. Pediatric Nephrology, $3^{\text {rd }}$ edition. Baltimore, Williams \& Wilkins 1999; 427-452

2. Yosypiv IV: Hypethesis: a novel role for the renin-angiotensin system in ureteric bud branching. Organogenesis 2004; 1: 26-32

3. Rossetti S, Harris PC: Genotype-phenotype correlations in autosomal dominant and autosomal recessive polycystic kidney disease. J Am Soc Nephrol 2007; $18: 1374-1380$

4. Costantini F: Renal branching morphogenesis: concepts, questions, and recent advances. Differentiation 2006; 74: 402-421

5. Brophy PD, Ostrom L, Lang KM, Dressler GR: Regulation of ureteric bud outgrowth by Pax2-dependent activation of the glial derived neurotrophic factor gene. Development 2001; 128: 4747 $-4756$.

6. Pachnis V, Mankoo B, Costantini F: Expression of the c-ret protooncogene during mouse embryogenesis. Development 1993; 119: $1005-1017$

7. Majumdar A, Vainio S, Kispert A, McMahon J, McMahon AP: Wnt11 and Ret/Gdnf pathways cooperate in regulating ureteric branching during metanephric kidney development. Development 2003; 130: $3175-3185$

8. Basson MA, Akbulut S, Watson-Johnson J, Simon R, Carroll TJ, Shakya R, Gross I, Martin GR, Lufkin T, McMahon AP, Wilson PD, Costantini FD, Mason IJ, Licht JD: Sprouty1 is a critical regulator of GDNF/RET-mediated kidney induction. Dev Cell 2005; 8: 229-239

9. Grieshammer U, Le Ma, Plump AS, Wang F, Tessier-Lavigne M, Martin GR:SLIT2-mediated ROBO2 signaling restricts kidney induction to a single site. Dev Cell 2004; 6: 709-717

10. Bouchard M: Transcriptional control of kidney development. Differentiation 2004; 72: 295-306

11. Miyazaki Y, Oshima K, Fogo A, Ichikawa I: Bone morphogenetic protein 4 regulates the budding site and elongation of the mouse ureter. J Clin Invest 2000; 105: 863-73.

12. Ekblom P: Developmentally regulated conversion of mesenchyme to epithelium FASEB J 1989; 3: 2141-2150

13. Hatini A, Huh SO, Herzlinger D, Soares VC, Lai E: Essential role of stromal mesenchyme in kidney morphogenesis revealed by targeted disruption of Winged Helix transcription factor BF-2. Genes and Development 1996; 10: 1467-1478

14. Mendelsohn C, Batourina E, Fung S, Gilbert T, Dodd J: Stromal cells mediate retinoid-dependent functions essential for renal development. Development 1999; 126: 1139-1148

15. Gomez RA, Lynch KR, Sturgill BC, Elwood JP, Chevalier RL, Carey RM, Peach MJ: Distribution of renin mRNA and its protein in the developing kidney. Am J Physiol 1989; 257: F850-F858

16. Yosipiv IV, Dipp S, El-Dahr SS: Ontogeny of somatic angiotensin-converting enzyme. Hypertension 1994; 23: 369-374

17. Norwood VF, Craig MR, Harris JM, Gomez RA: Differential expression of angiotensin II receptors during early renal morphogenesis. Am J Physiol 1997; 272: R662-R668

18. Yosipiv IV, El-Dahr SS: Activation of angiotensin-generating systems in the developing kidney. Hypertension 1996; 27:281286

19. Kakuchi J, Ichiki T, Kiyama S, Hogan BL, Fogo A, Inagami T, Ichikawa I: Developmental expression of renal angiotensin II receptor genes in the mouse. Kidney Int 1995; 47: 140-147

20. Garcia-Villalba P, Denkers ND, Wittwer CT, Wittwer CT, Hoff C, Nelson RD, Mauch TJ: Real-time PCR quantification of AT1 and 
AT2 angiotensin receptor mRNA expression in the developing rat kidney: Exp Nephrol 2003; 94: e154-159

21. Nagata M, Tanimoto K, Fukamizu A, Kon Y, Sugiyama F, Yagami $\mathrm{K}$, Murakami K, Watanabe T: Nephrogenesis and renovascular development in angiotensinogen-deficient mice. Lab Invest 1996; 75:745-753

22. Niimura F, Labosky PA, Kakuchi J, Okubo S, Yoshida H, Oikawa T, Ichiki T, Naftilan AJ, Fogo A, Inagami T: Gene targeting in mice reveals a requirement for angiotensin in the development and maintenance of kidney morphology and growth factor regulation. J Clin Invest 1995; 96:2947-2954

23. Takahashi N, Lopez ML, Cowhig JE Jr, Taylor MA, Hatada T, Riggs E, Lee G, Gomez RA, Kim HS, Smithies O: Ren1c homozygous null mice are hypotensive and polyuric, but heterozygotes are indistinguishable from wild-type. J Am Soc Nephrol 2005; $16125-16132$

24. Esther CR Jr. Howard TE. Marino EM. Goddard JM. Capecchi MR. Bernstein KE: Mice lacking angiotensin-converting enzyme have low blood pressure, renal pathology, and reduced male fertility. Lab Invest 1996; 7: 953-965

25. Oliverio MI, Kim HS, Ito M, Le T, Audoly L, Best CF, Hiller S, Kluckman K, Maeda N, Smithies O, Coffman TM: Reduced growth, abnormal kidney structure, and type $2\left(\mathrm{AT}_{2}\right)$ angiotensin receptor-mediated blood pressure regulation in mice lacking both $\mathrm{AT}_{1 \mathrm{~A}}$ and $\mathrm{AT}_{1 \text { B }}$ receptors for angiotensin II. Proc Natl Acad Sci USA 1998; 95: 15496-15501

26. Tsuchida S, Matsusaka T, Chen X, Okubo S, Niimura F, Nishimura $\mathrm{H}$, Fogo A, Utsunomiya $\mathrm{H}$, Inagami $\mathrm{T}$, Ichikawa I: Murine double nullizygotes of the angiotensin type $1 \mathrm{~A}$ and $1 \mathrm{~B}$ receptor genes duplicate severe abnormal phenotypes of angiotensinogen nullizygotes. J Clin Invest 1998; 101:755-760

27. Miyazaki Y, Tsuchida S, Fogo A, Ichikawa I. The renal lesions that develop in neonatal mice during angiotensin inhibition mimic obstructive nephropathy. Kidney Int 1999; 55: 1683-1695

28. Miyazaki Y, Tsuchida S, Nishimura H, Pope JC, Harris RC, McKanna JM, Inagami T, Hogan BL, Fogo A, Ichikawa I: Angiotensin induces the urinary peristaltic machinery during the perinatal period. J Clin Invest 1998; 102: 1489-1497

29. Yoo KH, Wolstenholme JT, Chevalier RL. Angiotensin-converting enzyme inhibition decreases growth factor expression in the neonatal rat kidney. Pediatr Res 1997; 42: 588-592

30. Tufro-McReddie A, Romano LM, Harris JM, Ferder L, Gomez RA: Angiotensin II regulates nephrogenesis and renal vascular development. Am J Physiol 1995; 38: F110-F115

31. Friberg P, Sundelin B, Bohman SO, Bobik A, Nilsson H, Wickman A, Gustafsson H, Petersen J, Adams MA. Renin-angiotensin system in neonatal rats: induction of a renal abnormality in response to ACE inhibition or angiotensin II antagonism. Kidney Int 1994; 45: 485-492

32. Schaefer C: Angiotensin II-receptor-antagonists: further evidence of fetotoxicity but not teratogenicity. Part A Clin Mol Teratol. Birth Defects Res 2003; 67:591-594

33. Tabacova S, Little R, Tsong Y, Vega A, Kimmel CA: Adverse pregnancy outcomes associated with maternal enalapril antihypertensive treatment. Pharmacoepidemiol Drug Saf 2003: 12: 633-646

34. Oshima K, Miyazaki Y, Brock JW, Adams MC, Ichikawa I, Pope $\mathrm{JC} 4^{\text {th }}$ : Angiotensin type II receptor expression and ureteral budding. J Urol 2001; 166: 1848-1852

35. Nishimura H, Yerkes E, Hohenfellner K, Miyazaki Y, Ma J, Hunley TE, Yoshida H, Ichiki T, Threadgill D, Phillips JA 3rd, Hogan BM, Fogo A, Brock JW 3rd, Inagami T, Ichikawa I: Role of the angiotensin type 2 receptor gene in congenital anomalies of the kidney and urinary tract, CAKUT, of mice and men. Mol Cell
1999; $3: 1-10$

36. Gribouval $\mathrm{O}$, Gonzales $\mathrm{M}$, Neuhaus T: Mutations in genes in the renin-angiotensin system are associated with autosomal recessive renal tubular dysgenesis. Nat Genet 2005; 37: 964-968

37. Lacoste M, Yi Cai Y, Liliane Guicharnaud et al. Renal Tubular Dysgenesis, a Not Uncommon Autosomal Recessive Disorder Leading to Oligohydramnios: Role of the Renin-Angiotensin System. J Am Soc Nephrol 2006; 17: 2253-2263

38. Iosipiv IV, Schroeder M: A role for angiotensin II AT1 receptors in ureteric bud cell branching. Am J Physiol 2003; 285: F199_ F207

39. Lopez ML, Pentz ES, Robert B, Abrahamson DR, Gomez RA: Embryonic origin and lineage of juxtaglomerular cells. Am J Physiol 2001; 281: F345-F356

40. Stirling D, Magness RR, Stone R, Waterman MR, Simpson ER: Angiotensin II inhibits luteinizing hormone-stimulated cholesterol side chain cleavage expression and stimulates basic fibroblast growth factor expression in bovine luteal cells in primary culture. J Biol Chem 1990; 265: 5-8

41. Srinivas S., Goldberg MR, Watanabe T, Dagati V, Al-Awqati Q, Costantini F: Expression of green fluorescent protein in the ureteric bud of transgenic mice: a new tool for the analysis of the ureteric bud morphogenesis. Dev Genetics 1999; 24: 241-251

42. Yosypiv IV, Schroeder M, El-Dahr SS. AT1R-EGFR crosstalk regulates ureteric bud branching morphogenesis. J Am Soc of Nephrol 2006; 17: 1005-1014

43. Karihaloo A, O'Rourke DA, Nickel C, Spokes K, Cantley LG: Differential MAPK pathways utilized for HGF- and EGF-dependent renal epithelial morphogenesis. J Biol Chem 2001; 276: 9166-9173

44. Sakurai H, Tsukamoto T, Kjelsberg CA, Cantley LG, Nigam SK. EGF receptor ligands are a large fraction of in vitro branching morphogens secreted by embryonic kidney. Am J Physiol 1997; 273: F463-472

45. Niimura F, Labosky PA, Kakuchi J, Okubo S, Yoshida H, Oikawa T, Ichiki T, Naftilan AJ, Fogo A, Inagami T: Gene targeting in mice reveals a requirement for angiotensin in the development and maintenance of kidney morphology and growth factor regulation. J Clin Invest 1995; 96: 2947-2954

46. Zhang SL, Moini B, Ingelfinger JR: Angiotensin II increases Pax-2 expression in fetal kidney cells via the AT2 receptor. J Am Soc Nephrol 2004; 15: 1452-1465.

47. Yosypiv I, Boh M, El-Dahr S: Angiotensin II- sprouty 1 crosstalk regulates ureteric bud branching morphogenesis. Pediatric Nephrology 2007; 22: 134A

48. Iosipiv IV: Cellular expression of the angiotensin type 2 receptor (AT2) during murine organogenesis. J Invest Med 2002; 50: $134 \mathrm{~A}$

49. Yosypiv IV, Schroeder M: Role of angiotensin type 2 (AT2) receptor in ureteric bud cell branching morphogenesis in vitro. J Am Soc Nephrol 2004; 15: 419A

50. Horiuchi M, Akishita M, Dzau VJ: Molecular and cellular mechanism of angiotensin II-mediated apoptosis. Endocr Res 1998; 24: $307-314$

51. Weiner ID, New AR, Milton AE, Tisher CC: Regulation of luminal alkalinization and acidification in the cortical collecting duct by angiotensin II. Am J Physiol 1995; 269: F730-F738

52. Tojo A, Tisher CC, Madsen KM: Angiotensin II regulates H+ATPase activity in rat cortical collecting duct. Am J Physiol 1994; 267: F1045-F1051

53. Wei Y, Wang W: Angiotensin II stimulates basolateral $\mathrm{K}$ channels in rat cortical collecting ducts. Am J Physiol 2003; 284: F175F181 